\title{
Tırnak Tutulumu Olan ve Olmayan Psoriazis Hastalarında Tırnak Yatağı ve Tırnak Plağı Kalınlığının Sonografik Olarak Değerlendirilmesi
}

\author{
Sonographic Evaluation of the Nail Plate and Nail Bed Thickness in Psoriasis Patient with and \\ Without Nail İnvolvement \\ Emine Nur Rifaioğlu', Nilgün Üstün²,Bilge Bülbül Şen',Özlem Ekiz \\ ${ }^{1}$ Mustafa Kemal Üniversitesi Tıp Fakültesi Dermatoloji Anabilim Dalı \\ ${ }^{2}$ Mustafa Kemal Üniversitesi Tıp Fakültesi Fiziksel Tıp ve Rehabilitasyon Anabilim Dalı
}

\begin{abstract}
öz
Amaç: Psoriazis toplumda \%1-3 sıklıkta görülen deri, eklemler ve tırnakları, tutan eritemli skuamlı inflamatuar bir hastalıktır. Psoriazis hastalarında tırnak tutulumu sıklığı \%15-\% 69 arasında değişmektedir. Ankilozan spondilit ise psoriatik artrit gibi seronegatif spondilartritlerdendir. Ultrasonografi günümüzde yumuşak dokuları değerlendirmek için yaygın kullanılan non invaziv bir görüntüleme yöntemidir.
\end{abstract}

Bu çalışmada tırnak tutulumu olan ve olmayan psoriazis hastalarında tırnak yatak ve tırnak plak kalınlıklarını ultrasonografik olarak ölçerek ankilozan spondilit hastaları ve kontrol grubu ile karşılaştırmayı hedefledik.

Gereç ve Yöntem: Otuzyedi psoriazis, 39 ankilozan spondilit hastası ile 33 sağlıklı kontrol çalışmaya dahil edildi. Psoriazis hastaları ile ankilozan spondilit ve kontrol grubunun "tırnak plak kalınlığı" ve "tırnak yatak kalınlığı" hasta oturur pozisyonda ve sağ el masa üzerinde nötral pozisyonda iken gri skala ultrasonografi (LOGIQ5Pre, GE, 4-11- MHz lineer prob) ile aynı hekim tarafından sağ el ikinci parmak tırnağında(indeks tırnak) ölçüldü.

Bulgular: Tırnak yatak kalınlıkları psoriazis, ankilozan spondilit ve kontrol grubunda sırasıyla 1.60,1.58,1.51 $\mathrm{mm}$ olarak ölçüldü. Tırnak plak kalınlıkları ise psoriazis, ankilozan spondilit ve kontrol grubunda sırasıyla 0.64,0.62,0.68 mm olarak ölçüldü. Psoriazis grubu ile ankilozan spondilit ve kontrol grupları arasında tırnak yatak ve tırnak plak kalınlıkları açısından istatistiksel olarak fark yoktu. $(p=0.13, p=0.45)$ Tırnak yatak kalınlığı, sağ el ikinci parmak tırnağı tutulumu olan hastalarda, olmayanlara göre istatistiksel olarak daha yüksek ölçüldü. $(p=0.030)$

Sonuç: Sonuç olarak çalışmamızda tırnak plak ve tırnak yatakkalınlıklarıultrasonografikolarakdeğerlendirildiğinde psoriazis grubu ile kontrol grubu ve ankilozan spondilit hastaları arasında fark bulunmadı. Ultrasonografik olarak ölçülen tırnak yatak kalınlıkları sağ el ikinci parmak tırnağı tutulumu olan hastalarda, olmayanlara göre istatistiksel olarak daha yüksekti.

Anahtar Kelimeler: Psoriazis; tırnak; ultrasonografi

\begin{abstract}
Objective: Psoriasis is an inflammatory and erythematousscaly disease which involve the skin, joint and nail. It's prevalence is $1-3 \%$. The incidence of nail involvement in psoriasis patient ranged between 15-69\%. Ultrasonography is a noninvasive imaging method widely using for assess the soft tissue image nowadays. In this study we aimed to assess the nail bed and nail plate thickness in psoriasis patient with and without nail involvement and compare with ankylosing spondylitis and control groups.
\end{abstract}

Material and Methods: Thirty-seven patient with psoriasis, 39 patient with ankylosing spondylitis and 33 healthy control were included to the study. Nail bad and nail plate thicknesses was measured with grey scale USG(LOGIQ5Pre, $\mathrm{GE}, 4-11-\mathrm{MHz}$ lineer prob) from the right hand's second finger(index finger), when the patient seated with the hands in a neutral position over the table.

Results: Nail bad thicknesses were measured as 1.60, 1.58, $1.51 \mathrm{~mm}$ respectively in psoriasis, ankylosing spondilytis and control groups. Nail plate thicknesses were $0.64,0.62$ and $0.68 \mathrm{~mm}$ respectively in psoriasis, ankylosing spondylitis and control groups. Nail bad and nail plate thickness were not statistically different between psoriasis, ankylosing spondylitis and control groups. $(p=0.13, p=0.45)$ Nail bad thicknesses were measured more in the psoriasis patient with righth and second finger nail involvement then without righth and second finger nail involvement. $(p=0.030)$

Conclusion: Inconclusion when evaluated the nail plate thickness ultrasonographically there was no statistically significant difference between psoriasis, ankylosing spondylitis and control groups. Nail bed thickness was statistically higher in psoriasis patients with righth and second finger nail involvement compared to non.

Keywords: Psoriasis; nail; ultrasonography 


\section{Giriş̧}

Psoriazis toplumda \%1-3 sıklıkta görülen deri, eklemler ve tırnakları, tutan eritemli skuamlı inflamatuar bir hastalıktır(1,2). \%1-10 hastada ise psoriazis sadece tırnak tutulumu ile seyredebilir(3). Psoriazis hastalarının \%80-90'ında hayatlarının bir bölümünde tırnak tutulumu görülmektedir(4).Psoriazis tırnak tutulumu tanısı klinik ve histopatolojik olarak konmaktadır. Ancak tırnak kozmetik olarak önemi olan bir organdır. Histopatolojik inceleme için biyopsi alınması skar bırakacağıdan hasta ve doktor tarafından tercih edilmemektedir. Ankilozan spondilit seronegatif spondilartritlerdendir. Sıklıkla aksiyel eklemleri tutar, bazen daktilit ve entezitle de seyredebilir(5).

Ultrasonografi günümüzde yüzeyel dokuları değerlendirmek için yaygın kullanılan non invaziv bir görüntüleme yöntemidir(6). Ultrasonografinin tırnak kalınlığını ve yapısını değerlendirmek için kullanımı 25 yıllık bir geçmişe dayanmaktadır(7). Noninvaziv görüntüleme yöntemlerinden magnetik resonans görüntüleme, optik koherans tomografi, konfokal mikroskopi de dermatolojide kullanılan noninvaziv görüntüleme yöntemlerindendir. Ancak yukarıda bahsettiğimiz görüntüleme yöntemleri tırnak yapısını ayrıntılı görmemizi sağlasalar da pahalıdır ve kolay ulaşılabilen yöntemler değillerdir $(8,9)$. Çalışmamızda tırnak tutulumu olan ve olmayan psoriazis hastalarında tırnak yatak ve tırnak plak kalınlığı ölçülerek ankilozan spondilit ve kontrol grubunu ile karşılaştırmayı hedeflendi.

\section{GEREÇ ve YÖNTEM}

Mustafa Kemal Üniversitesi Tıp Fakültesi Dermatoloji Anabilim Dalı Polikliniğine başvuran 37 ardışık psoriazis hastası ile Mustafa Kemal Üniversitesi FizikTedavi ve rehabilitasyon polikliniğine başvuran 39 ankilozan spondilit ile 33 ardışık sağlıklı kontrol çalışmaya dahil edildi. Mustafa Kemal Üniversitesi Tıp Fakültesi Etik Kurulunun onayı alındı. Hasta ve kontrollerin bilgilendirilmiş onayı alındı. Onikomikoz, liken planus, gibi tırnak tutulumu olan hastalar çalışmaya dahil edilmedi. Psoriazis hastalarının hastalık süresi, psoriazis tipi, tırnak tutulum tipi(pitting, subungual hiperkeratoz, onikoliz, splinter hemoroji, yağ lekesi, kırmızı lunula, lökonişi, çomaklaşma.) psoriazis alan şiddet indeksi (PASI), kaydedildi(10). Tüm hastalar için yaş, cinsiyet, kilo, boy, vücut kitle indeksi, kaydedildi. Tırnak tutulumu olan psoriazis hastalarının tırnak psoriazisi şiddet indeksi (NAPSI) değerleri hem total olarak hem de sağ el ikinci parmak tırnağında(indeks tırnak) aynı hekim tarafından hesaplandı(11). Tırnak tutulumu olan ve olmayan psoriazis hastaları ile ankilozan spondilit ve kontrol grubunun "tırnak plak kalınlığı" ve "tırnak yatak kalınlığı" hasta oturur pozisyonda ve sağ el masa üzerinde nötral pozisyonda iken gri skala ultrasonografi (LOGIQ5Pre, GE, 4-11- MHz lineer prob) ile aynı hekim tarafından sağ el 2. parmak tırnağında ölçüldü.

İstatistiksel hesaplamalariçin SPSS v. 19 software program kullanıldı. Kategorik değerlerin karşılaştırılmasında ki kare testi kullanıldı. İki grupta numerik değerlerin karşılaştırması için Mann Whitney $U$ ve Student $T$ testi kullanıldı. İkiden fazla bağımsız grupta numerik değerlerin karşılaştırması için One way Anova testi kullanıldı. $\mathrm{P}<0.05$ anlamlı kabul edildi.

\section{BULGULAR}

Yirmi bir erkek (\%56.8), 16 (\%43.2) kadın toplam 37 psoriazis hastasının yaş ortalaması 35.73 idi (Tablo 1). Psoriazis hastalarının ortalama PASI değeri 6.76, ortalama NAPSI değeri 9.5 idi (Tablo 1). Psoriazis hastalarının 21'inde tırnak

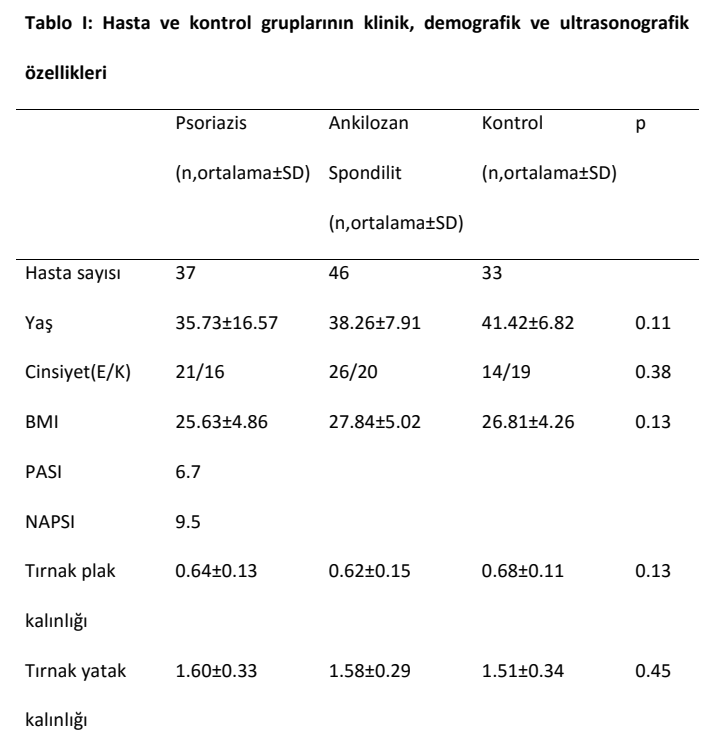

BMI : Vücut kitle indeksi PASI:Psoriazis alan şiddet indeksi NAPSI: Tırnak psoriazisi şiddet indeksi

tutulumu vardı. Psoriazis grubunda sağ el ikinci parmak tırnaktan USG ile ölçülen ortalama tırnak yatak kalınlığı ve ortalama tırnak plak 
kalınlığı sırasıyla 1.60 ve 0.64 mm'ydi (Tablo 1). Yirmialtı (\% 56.5) erkek, 20(\%43.5) kadın toplam 46 ankilozan spondilit hastasının ortalama yaşları 38.26 idi. Ankilozan spondilit grubunda USG ile ölçülen ortalama tırnak yatak kalınlığı ve ortalama tırnak plak kalınlığı sırasıyla 1.58 ve 0.62 mm'ydi (Tablo 1). Ondört (\% 43.2) erkek,19 (\% 56.8) kadın toplam 33 kontrolün yaşları ortalaması 41.42 idi. Kontrol grubunda USG ile ölçülen ortalama tırnak yatak kalınlığı ve ortalama tırnak plak kalınlığı sırasıyla 1.51 ve 0.68 mm'ydi (Tablo 1). Tüm gruplar yaş, cinsiyet, tırnak plak kalınlığı, tırnak yatak kalınlığı açısından karşılaştırıldığında arada İstatistiksel olarak fark yoktu. Tırnak tutulumu olan psoriazis hastalarında en sık pitting ve ikinci sırada onikoliz görülürken, en az sıklıkta splinter hemoroji izlendi (Tablo 2). Tırnak yatak kalınlığı Sağ el ikinci parmak tırnağı tutulumu olan hastalarda, olmayanlara göre istatistiksel olarak daha fazlaydı (Tablo 3).

\begin{tabular}{lcc}
$\begin{array}{l}\text { Tablo 2: Toplam tırnak tutulumu ve indeks tırnak tutulumu olan } \\
\text { bulgularının dağııımı }\end{array}$ & \\
\hline & Toplam tırnak & Indeks tırnak \\
tutulumu(n,(\%)) & tutulumu(n,(\%)) \\
\hline Tırnak Tutulumu & $21(56.8)$ & $17(45.9)$ \\
Pitting & $12(32.4)$ & $9(24.3)$ \\
Onikoliz & $6(16.2)$ & $5(13.5)$ \\
Subungual hiperkeratoz & $4(10.8)$ & $3(8.1)$ \\
Splinter hemoroji & $1(2.7)$ & $1(2.7)$ \\
Yağ lekesi & 0 & 0 \\
Lökonişi & $2(5.4)$ & 0 \\
Lunulada kırmızı spot & $1(2.7)$ & 0 \\
Çomaklaşma & $1(2.7)$ & $1(2.7)$ \\
\hline
\end{tabular}

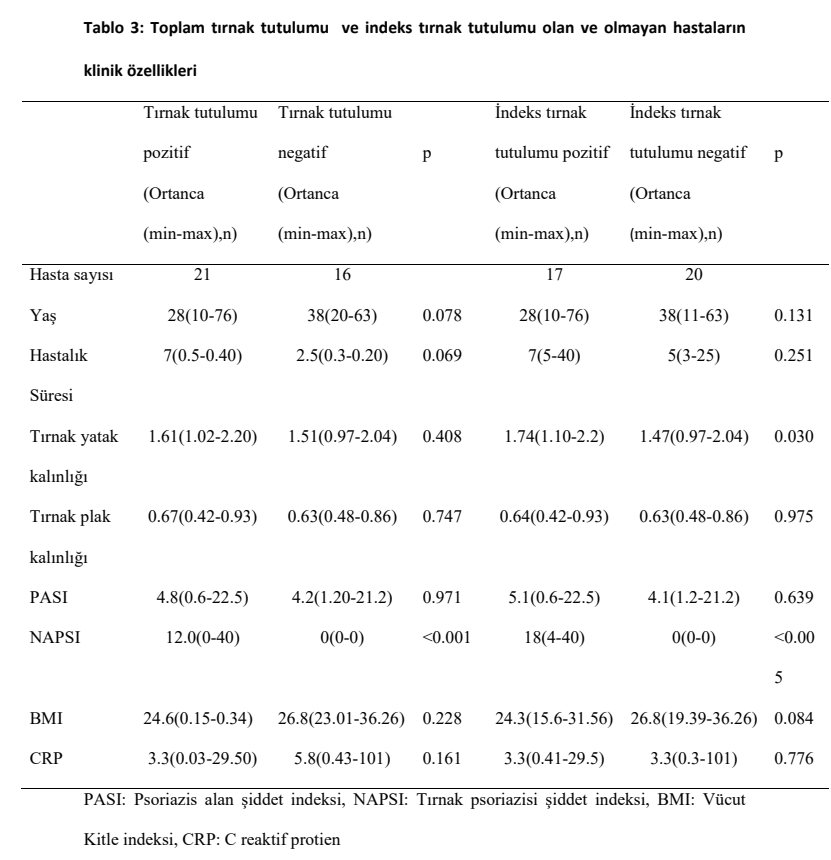

\section{TARTIŞMA}

Çalışmamızın sonucunda psoriazis, ankilozan spondilitvekontrol gruplarıarasındatırnakyatak ve tırnak plak kalınlıkları açısından istatistiksel fark bulunmadı. Psoriazis, kronik ekzema ve kontrol gruplarının, tırnak plak ve tırnak yatak kalınlıkları açısından ultrasonografik olarak karşılaştırıldığıbirçalışmada, tırnakplakvetırnak yatak kalınlıkları psoriazis grubunda istatistiksel olarak daha yüksek bulunmuştur (12). Gutierrez ve arkadaşlarının çalışmasında ise sağ el ikinci parmak tırnağında ölçülen tırnak yatak kalınlığı psoriazis grubunda ortalama $3 \mathrm{~mm}$ iken kontrol grubunda $1.5 \mathrm{~mm}$ bulunmuştur (13). Bizim çalışmamızda ise psoriazis grubunda ölçülen tırnak yatak kalınlıkları, , ankilozan spondilit ve kontrol grubuna oranla daha kalın olmakla beraber aradaki fark istatistiksel olarak anlamlı değildi.

Ultrasonografik ölçümün yapıldığı sağ el ikinci parmak tırnağı tutulumu olan hastalarda, tırnak yatak kalınlığı tutulum olmayanlara göre istatistiksel olarak daha kalın bulundu. Bizim çalışmamızın diğer çalışmalardan farkı tırnak tutulumu olan ve olmayan hastaların da birbiri ile karşılaştırılmış olmasıdır. Diğer iki çalışmada ise bizim çalışmamızdan farklı olarak çalışmaya dahil edilen tüm psoriazis hastalarının tırnak tutulumu mevcuttu $(12,13)$.

Çalışmamızda psoriazis hastalarında tırnak tutulum oranı \%56.8 olarak saptandı. Bu oran literatür ile uyumluydu $(1,2,14)$. En sık görülen tırnak tutulumu pitting, en az görülen ise splinter hemoraji olarak saptandı. Hiçbir hastada yağ lekesi bulgusuna rastlanmadı. Tırnak tutulum oranları Gisondi'nin çalışması ile benzerdi (12). Bir olguda sedece tırnak tutulumu vardı. Psoriazis \% 1-10 oranlarında sadece tırnak tutulumu ile başvurabilir(3).

Çalışmamızda PASı ile tırnak tutulumu arasında ilişski yoktu. Oysa Radke ve arkadaşlarının bir çalışmasında tırnak tutulumu olan psoriazis hastalarında psoriazis vücut yüzey alanı istatistiksel olarak daha yüksek bulunmuştur (15). Çalışmamızda PASI ile NAPSI değerleri arasında da ilişki bulunmadı.

Çalışmamızda ankilozan spondilit hastaları ile 
psoriazis ve kontrol grubu arasında tırnak yatak kalınlığı ve tırnak plak kalınlığı açısından istatistiksel fark yoktu. Wendling ve arkadaşlarının yaptıkları bir çalışmada ankilozan spondilit hastalarında tırnak yatağı kapilleroskopik olarak değerlendirildiğinde kontrol grubuna göre belirgin mikroanjiopati ve ödem izlendiği görülmüştür (16). Bizim çalışmamızda ise ankilozan spondilit hastalarında ortalama tırnak yatak kalınlığı kontrol grubuna oranla daha kalın bulunmakla beraber fark istatistiki olarak anlamlı değildi. Bu durum olgu sayısının azlığı ile ilişkili olabilir.

Psoriazis tırnak tutulumu gerek kozmetik açıdan gerekse fonksiyonel açıdan hastaları olumsuz yönde etkilemektedir. Tırnak tutulumu şiddeti en yaygın olarak NAPSI skoru ile hesaplanmaktadır (11). Bunun yanında tırnak tutulumunun şiddeti ve tipi çeşitli görüntüleme yöntemleri kullanılarak da değerlendirilmiştir. Bunlar ultrasonografi, optik koherans tomografi ve konfokal mikroskopidir (17-19). Görüntüleme yöntemleri arasında en kolay ve ucuz olan yöntem ise ultrasonografidir.

Sonuç olarak çalışmamızda tırnak plak kalınlıkları ultrasonografik olarak değerlendirildiğinde kontrol grubu ve ankilozan spondilit hastaları ile arada fark bulunmadı. Tırnak yatak kalınlıkları psoriazis grubunda kontrol ve ankilozan spondilit grubuna oranla yüksek bulunmakla beraber aradaki fark istatistiksel olarak anlamlı değildi. Tırnak yatak kalınlığı sağ el ikinci parmak tırnağı tutulumu olan hastalarda olmayanlara göre istatistiksel olarak daha kalın ölçüldü. Çalışmamızın kısıtlayıcıları, psoriazis grubunda tırnak tutulumu olan hasta sayımızın azlığıdır. Bu konuda tırnak tutulumu tipinin de göz önünde bulundurularak, daha geniş hasta serileri ile yapılacak çalışmalara ihtiyaç vardır.

\section{KAYNAKLAR}

1. Jiaravuthisan MM, Sasseville D, Vender RB, F. Murphy, Muhn CY. Psoriasis of the nail: anatomy, pathology, clinical presentation, and a review of the literature on therapy. J Am Acad Dermatol 2007;57(1):1-27.

2. Kyriakou A, Patsatsi A, Sotiriadis D. Detailed analysis of specific nail psoriasis features and their correlations with clinical parameters: a cross-sectional study. Dermatology 2011;223(3):222-9.
3. Baran R.Theburden of nail psoriasis: an introduction. Dermatology 2010;221(Suppl 1):1-5.

4. Van der Velden HM, Klaassen KM, van de Kerkhof PC, Pasch MC. Finger nail psoriasis reconsidered: a casecontrol study. J Am Acad Dermatol 2013;69(2):245-52.

5. Glasnović M, Bosnjak I, Sram M, et al. Clinical characteristics of patients with spondylo arthritides and HLA-B27 positive antigen. Coll Antropol 2011;35(2):397402.

6. Ch'ng SS, Roddy J, Keen HI. A systematic review of ultrasonography as an outcome measure of skin involvement in systemic sclerosis. Int $J$ RheumDis 2013;16(3):264-72.

7. Jemec GB, Serup J.Ultrasound structure of the human nail plate. Arch Dermatol 1989;125(5):643-6.

8. Dalbeth N, Pui K, LoboM et al. Nail disease in psoriatic arthritis: distal phalangeal bone edema detected by magnetic resonance imaging predicts development of onycholysis and hyperkeratosis. J Rheumatol 2012;39(4):841-3.

9. Sattler E, Kaestle R, Rothmund G, Welzel J. Confocal laser scanning microscopy, optical coherence tomography and trans onychial waterloss for in vivo investigation of nails. Br J Dermatol 2012;166(4):740-6.

10. Jemec GB, Wulf HC. The applicability of clinical scoring systems: SCORAD and PASI in psoriasis and atopic dermatitis. Acta Derm Venereol 1997;77(5):392-3.

11. Aktan S, Ilknur T, Akin C, Ozkan S. Inter observer reliability of the Nail Psoriasis Severity Index. Clin Exp Dermatol. 2007;32(2):141-4.

12. Gisondi $P$, Idolazzi $L$, Girolomoni G. Ultrasonography reveals nail thickening in patients with chronic plaque psoriasis. Arch Dermatol Res 2012;304(9):727-32.

13. Gutierrez M, Wortsman X, Filippucci $E$, De Angelis R, Filosa G, Grassi W. High-frequency sonography in the evaluation of psoriasis: nail and skin involvement. J UltrasoundMed 2009;28(11):1569-74.

14. Güler ÇF, Özden M, Aydın F, ve ark .Psöriyazis olgularında tırnak tutulum oranları ve NAPSI-PASI korelasyonu. Turkiye Klinikleri J Dermatol 2010;20(2):559.

15. Radtke MA, Langenbruch AK, Schafer I, Herberger $K$, Reich K, Augustin M. Nail psoriasis as a severity indicator: results from the Pso Real study. Patient Relat Outcome Meas $2011 ; 2(1): 1-6$.

16. Wendling D, Risold JC. Nail fold capillaroscopy and ankylosing spondylarthritis: incidence of anomalies, but absence of diagnostic and prognostic value. Rev Med Interne 1994;15(7):448-51. 
17. Sandobal C, Carbo E, Iribas J, Roverano S, Paira S. Ultrasound nail imaging on patients with psoriasis and psoriatic arthritis compared with rheumatoid arthritis and control subjects. J ClinRheumatol 2014;20(1):21-4.

18. Cinotti E, Fouilloux B, Perrot JL, Labeille B, Douchet C, Cambazard F. Confocal microscopy for healthy and pathological nail. J Eur Acad Dermatol Venereol 2013doi: 10.1111/jdv.12330.

19. Aydin SZ, Castillo-Gallego C, AshZR,et al. Potential use of optical coherence tomography and high-frequency ultrasound for the assessment of nail disease in psoriasis and psoriatic arthritis. Dermatology 2013;227(1):45-51. 